\title{
The Influence of Technology and Information on Student's Behavior: a Case Study of SMA Negeri 1 of Pantai Cermin at Serdang Bedagai
}

\author{
Suwardi Lubis ${ }^{1}$, Riza Buana ${ }^{2}$ \\ 1,2Faculty of Social and Political Sciences, Universitas Sumatera Utara, Indonesia \\ Email: lubis.suwardi@yahoo.co.id
}

\begin{abstract}
:
The progress of information technology is very influential in life. The changing of student's behavior will be seen clearly now days than before. Apart from all kinds of controversies. This case full of controversies, but the students could not be separated from technology and the internet. The internet itself has a negative effect and positive effect. Human's interaction also can be change unconditionally. This technology, specially in communication and media have shown a new page in daily life and influence the social life and social behavior. This research is aimed to know the purpose of the information technology and communication to support the student's development effectively and efficiently and to know how the student's social behavior and the effect of using information technology and communication to the student's social behavior in SMA N 1 Pantai Cermin. The results of this research showed that mobile phone and the internet as a form of technological development had positive and negative impacts on the cognitive development and moral behavior of students. The positive impact of using mobile phones is the most effective and efficient communication tool and also the media for accessing information related to education.
\end{abstract}

Keywords:

information technology; student behavior; social behavior

\section{Introduction}

The development of science and technology has driven progress in all areas of life, including progress in the field of information technology. This has opened up opportunities for mankind to access all information globally which results in the occurrence of a world phenomenon without borders (bord rless world). Events occurring in one part of the world can easily be known by people in other parts of the world.

The internet currently plays a large role in human life and technological advances now days to support this role so computer and internet technology are utilized in various fields such as doing schoolwork, studying, managing family finances, listening to music, watching videos, and enjoying games (Effendy, Onong Uchjana, 2005).

Technology and communication have a relation because communication requires technology in its progress. Communication is the process of delivering messages by someone to other people to tell, change attitudes, opinions or behavior either directly orally or indirectly through the media. In this communication requires a reciprocal relationship between the delivery of messages and recipients namely communicators and communicants (Hasbullah in Amin, 2019). 


\section{Britain International of Humanities and Social Sciences (BIoHS) Journal \\ ISSN: 2685-3868(Online), 2685-1989(Print) \\ Vol. 2, No. 2, June 2020, Page: 523-528}

Technology is very important indeed. So that in social life, the term "Communication Technology" is known. This term is familiar to our ears. Humans are now mixed with communication technology. According to BNET Business Dictionary (2008), Communication Technology is an electronic system used to communicate between individuals or groups of people. The Oxford dictionary (1995) stated that information technology is the study or use of electronic equipment, especially computers, to store, analyze, and distribute any information, including words, numbers, and images.

Meanwhile (Erner J: 2011), said that information technology includes hardware and software to carry out one or some data processing tasks such as capturing, transmitting, storing retrieve, manipulate, or display data, Meanwhile (Munir), mentioned that information technology is not only limited to computer technology (hardware and software) that was used to process and store, but also includes communication technology for sending information. While Setiadi, Julianto Arief, et al. 2009, argue that information technology is any form of technology applied to process and transmit information in electronic form. Communication technology facilitates communication between individuals or groups of people who do not meet physically in the same location.

The main purpose of information technology to help in solving problems with high creativity and make people more effective in using them. The principle of "High-tech" is increasingly "high-tech information technology that we consider the" high-touch "aspect of information technology that is the human aspect. But don't ask humans to adapt to technology.

Understanding Social Behavior according to Syam, Nina W. (2012) that the notion of behavior is "A reflection of one's personality that is seen in actions and interactions with others in the surrounding environment." Human dependence on smartphones seems changed the position of the object as a new family member that can hardly be separated from everyday life. He appeared to be something that can change the lifestyle of humans in the family. Even smartphone has been able to affect the life of the state.

Teenagers were unable to choosethe activity of the internet that usefull and tend to be easily influenced by the social environment without first considering the positive or negative effects that will be received when doing certain internet activities. Therefore, it is not surprising that so far the online behavior of adolescents have always been the main spotlight to be studied, both by the government and the academic environment.

The case study at the research location was one of the places that have affected by the development of information and communication technology in particular (Mobile Smartphone). Students have easy access to a variety of Information and Communication tools, one of which is the handphone (HP). Mobile phones used by students are not just for communicating, doing schoolwork, looking for reference material, tools for buying and selling transactions, listening to music, but not infrequently the smartphone cellphones are misused by some students to view sites that are not should be seen by students or among students including violent sites, pornographic sites, and online games.

The development of information technology today is increasingly rapid, various technological advances can be obtained easily. Along with the times and the rapid development of technology, communication between humans can be done with various tools or means. (Mobile) is increasingly prevalent among the public ranging from bureaucrats, businessmen, mothers, students, students, taxi drivers, motorcycle taxi drivers, to sellers. This 
is a sign that the use of cell phones is no longer intended as a symbol of prestige, but rather is used more for business purposes, organization, and family matters. 6Handphone has now become a basic need for Indonesian people from the lower, middle and upper classes, already using mobile phones, especially at prices that are offer quite affordable. In the rapid development of the information world is very unlikely for people to be separated from technology in their lives.

Many functions of the use of mobile phones, including mobile phones as entertainment media, delivery of information via SMS, Facebook, Twitter, Google, and so forth. In essence, technological progress and its influence in life are things we cannot avoid, because today we can see how technological advances that have influenced lifestyles and people's behavior, indeed the influence of technological advances in the past and in today's times is different, in the past technology has not as sophisticated as today.

This research will discuss the role of information and communication technology to support progress/development in students: Case Study of SMA N 1 Pantai Cermin Serdang different effectively and efficiently, and to find out How is the social behavior of students and the impact of the use of information and communication technology on The social behavior of class XI students at SMA N 1 Pantai Cermin.

\section{Research Method}

This research used descriptive qualitative method with the case study method. Case study research or field study is intended to study intensively about the background of the problem of the state and position of an event that is taking place at this time, as well as the interaction of certain social units that are given. Data collection techniques using observation, in-depth interviews, documentation, and triangulation. In this study, the snowball sampling technique was used in determining the informants meaning that the search for informants would be stopped after the research information was considered to be sufficient. Data analysis techniques through three stages, namely data reduction, data presentation, and data verification, and data of analysis conclusion. The subjects of this study were students in SMA N 1 Pantai Cermin Serdang Bedagai.

\section{Discussion}

\subsection{The Impact of Using Technology of Information in the Form of Mobile on Student's Behavior}

The use of information and communication technology for SMA N 1 Pantai Cermin students is very good if for the learning process because the school has provided computer lab facilities and Wi-fi for facilities that can be used by students. SMA N 1 Pantai Cermin is a school that has advanced because in the process of learning it uses adequate information and communication technology tools for students, and SMA N Pantai Cermin is also one of the schools in the implementation of computer examinations that use computer-based in its implementation. But the information and communication technology of mobile phones the school does not allow students to bring mobile phones to school because it will adversely affect their students, if students carry mobile phones to school then their learning will be disrupted, the focus of students will be divided between the subject matter with the handphone that is being played.

Based on the research findings explained that the use of information and communication technology in SMA N 1 Pantai Cermin in general from year to year there is 
progress from the facilities provided by the school to students is very good because now the number of computers in schools has increased from the previous year, the use of information and communication technology especially mobile phones that researchers found in the observation that although there were already rules of school rules that should be obeyed by their students there were students who violate these rules, students who take advantage of the careless teacher supervision secretly dare to bring the cellphone to school even dares to use the cellphone during class time, this occurs the possibility of lack of strict supervision from teachers and the lack of sanctions imposed on students who violate these regulations and had not given a deterrent effect to their students.

The impact of using information and communication technology, especially mobile phone, is aware that we have never been aware of them. The impact of using the information divided into two, they are positive and negative impacts. The positive or negative impact that occurs from the use of information and communication technology depends on its using. if people who are controlled by technology are likely have a negative hurt impact on the users of the technology, but conversely if people who are good at using technology tools properly and wisely then users feel the benefits of these tools.

\subsection{Impact of Social Media on Student's Behavior}

Media effects (media effects) are changes in awareness, attitudes, emotions, or behavior that are the result of interactions with the media. The term is often used to describe changes in individuals or society caused by exposure to the media. The development of thought and theory about the impact of the media has a natural history because it is influenced by the setting of time, place, environmental factors, technological change, historical events, the activities of pressure groups, propagandists, public opinion tendencies, as well as a variety of discoveries and tendencies that are developing in the study of social sciences.

According to researchers, looking at the statements of several informants with several theories concluded that the results of the impact of the use of information and communication technology on students' social behavior did not occur so that large changes, changes in awareness, attitudes, emotions, or behavior that are the result of interactions with the media. Changes in the social behavior of students have more impact on themselves and other students than on the teacher. Student behavior towards teachers is still good, nothing deviates, and students continue to behave well, behave politely with teachers and students who carry smartphone smartphones to school more often use smartphone smartphones during breaks than during class time.

The impact of the using of mobile phones for social media during the break then interaction between one student and other students becomes disrupted, students who play their mobile phones tend to focus more on what they are playing and do not care about the surrounding environment. Therefore there was a change in social behavior among students with other students. The more time spent socializing and interacting in cyberspace makes the less time spent to socialize and interact with other people in the real world then it will be difficult to read body language in communication that is always inherent when communicating. As a result, he becomes less able to communicate effectively in face-to-face communication.

Active students in using social media could reduce student attention to learning material. This is because students are too busy checking the latest status of others and then giving comments. This distracted attention can disrupt the learning process and had an impact on students' ability to concentrate which later leads to a drop in academic achievement. The presence of social media in the universe of communication between humans had a major 
impact on patterns of communication between people, especially interpersonal communication or interpersonal communication. In other words, social media influences individual patterns of interaction and this is also an example of the effect of media in individual interactions. Social media is effective in helping shy students to communicate with other students or others. But it had an impact on communication skills directly or face to face. If shy students often use social media to interact and express themselves, this can make them feel isolated in the real world and can even increase communication anxiety for fear of meeting other students or people.

\subsection{Impact of the Internet on Student's Behavior}

The results of researchers' interviews with students related to the positive impact of the use of the Internet are all said that the internet today as a medium of information in learning as a medium for disseminating information. Up to date information is very easy to spread through social networking sites. Only within a few minutes after the incident, we have been able to enjoy the information. Most teenagers use it as a communication medium because it is more effective and efficient. The benefits of the internet as a medium of learning and entertainment, all say that they use the internet as a medium of entertainment to play online games, download games, the latest songs through Google.

While the negative impact obtained from the internet was the misuse of the Internet on pornographic content that can affect the mentality and behavior of students, cybercrime. Crimes are known as cybercrime. Cybercrime is very diverse. Among them: carding, hacking, cracking, phishing, and spamming.

\subsection{The Solution have done by Pantai Cermin N 1 High School Fortify Students from the Negative Impacts of the Use of Information Technology}

The efforts of the school which was considered to be the most ideal in overcoming negative student behavior due to the use of mobile phones as well as negative information accessed from the internet, the principal and all teachers interviewed think that the most effective way are:

1. Equipping students with religious knowledge and what they have done, every Friday there is a service held with students and teachers at school.

2. Raids mobile phones by the school. It was believed that the school could provide a deterrent effect for students to save pornographic images or videos on mobile phones. And to monitor student activities outside the classroom or during recess, the school gives responsibility to each student council member.

3. Good cooperation between teachers and parents, in the form of mutual information about the development of behavior, and student learning abilities at home and school, such as a statement from the Principal of SMA N 1 Pantai Cermin.

\section{Conclusion}

Students of SMA Negeri 1 Pantai Cermin used information technology generally that is applied to the internet (smartphone), with various applications available on smartphones, this gadget provided positive benefits for students, as an effective and efficient communication tool in communicating through direct long-distance and in on-line and also as a medium of information that students could use according to their needs, including in supporting education. Furthermore, excessive use of mobile phones has hurt student health but it was considered not important even though the effect has been felt, and the most important thing is cognitive development that motivation in student learning is reduced. 
The field of information and communication technology is developing rapidly, triggered by findings in the field of microelectronic material engineering. These developments affect various aspects of life, even human behavior and activities now depend a lot on information and communication technology

\section{Acknowledgment}

I thank the research institute of the Universitas Sumatera Utara, for the research funding assistance and to the assistants and staff who assisted this paper.

\section{References}

Amin, M., A. (2019). Marketing Communication Strategy To Improve Tourism Potential. Budapest International Research and Critics Institute-Journal (BIRCI-Journal). p. 160166.

Erner J. Severin, James W. Tankard, JR. (2011). Teori Komunikasi Sejarah. Metode, dan TeraPan di Dalam Media Massa. Cetakan ke 5. Terjemahan Sugeng Hariyanto. Jakarta: Kencana

Effendy, Onong Uchjana. (2005). Ilmu Komunikasi Teori dan Komunikasi. Bandung: Remaja Rosdakarya.

Heri Budianto, Farid Hamid (Ed.). (2014). Ilmu Komunikasi Sekarang dan Tantangan Masa Depan. Jakarta: Kencana Prenadamedia Group. Cetakan ke 2.

M. Burhan Bungin. (2014). Sosiologi Komunikasi, Teori, Paradigma dan Diskursus Teknologi Komunikasi di Masyarakat. Jakarta: Kencana Prenadamedia Group, Cet.14 . (2015). Konstruksi Sosial Media Massa. Jakarta: Kencana Prenadamedia Group. Cetakan ke 3.

Morrisan. (2014). Teori Komunikasi Massa Individu Hingga Massa. Jakarta: Kencana Prenadamedia Group. Cetakan ke 2.

Munir, (2010) Kurikulum Berbasis Tekhnologi Informasi dan Komunikasi. Bandung : Alfa Beta.

Nikmah, Astin (2014). Dampak Penggunaan Handphone terhadap Prestasi Siswa. Surabaya: E-jurnal Dinas Pendidikan

Setiadi, Julianto Arief et al. (2009). Teknologi Informasi dan Komunikasi. Ristek:Jakarta.

Syukur Kholil (Ed.). (2011). Teori Komunikasi Massa. Bandung: Citapustaka Media Perintis.

Syam, Nina W.(2012). Psikologi Sosial. Bandung: Simbiosa Rekatama Media

Stephen W. Littlejohn, Karen A. Foss. Theories of Human Communication. BelmontbCalifornia. Edisi ke 9. Penerjemah Muhammad Yusuf Hamdan. Jakarta: Salemba Humanika.

Sugiyono. (2007). Metode Penelitian Kuantitatif, Kualitatif dan R \& D. Bandung: Alfabeta.

Werner J. Severin, James W. Tankard. (2011). Teori Komunikasi Sejarah, Metode, dan Terapan di Dalam Media Massa. Jakarta: Kencana Prenadamedia Group. Edisi ke Kelima. 